\title{
Serum thymus and activation-regulated chemokinelevels in children with atopic dermatitis
}

\author{
Tamila Sorokman', Snizhana Sokolnyk', Iryna Sokolnyk², \\ Olena Makarova ${ }^{3}$, Pavlo Moldovan ${ }^{4}$ \\ ${ }^{1}$ Department of Pediatrics and Medical Genetics, \\ Bukovinian State Medical University, Chernivtsi, Ukraine \\ ${ }^{2}$ Bukovinian State Medical University, Chernivtsi, Ukraine \\ ${ }^{3}$ Department of Higher Nursing Education, Bukovinian State Medical University, Chernivtsi, Ukraine \\ 4"Bukintermed" Laboratory, Chernivtsi, Ukraine
}

\begin{abstract}
Introduction. It is known that atopic dermatitis (AD) is characterized by infiltration of Th2 cells into affected skin. Infiltration of inflammatory cells in the tissue is mediated by specific chemokines. An important chemokine is Thymusand Activation-Regulated Chemokine (TARC). The purpose of the study is to investigate TARC levels in blood serum of children of different ages with different $A D$ severity degrees. Methods. The scrunity of immune status was conducted in 168 children with $A D$ aged from 1 to 18 years. The inclusion criteria in the study were: age of patients from 1 to 18 years; residence in Chernivtsi region; confirmed AD. The severity of AD was set by the SCORAD Index. Serum IgE and TARC levels were determined.

Results. Often, AD has occurred in young children, particularly from 2 to 6 years of age. The most prevalent in children with $A D$ is food sensibilisation, which is found in $89.9 \%$ of cases. With age, the level of allergenic lgE in the blood of patients with $A D$ and sensibilisation increased. The average indicator in the group of children with $A D$ was 1322.8 $\pm 114.6 \mathrm{pg} / \mathrm{ml}$, while in the group of healthy children $-399.8 \pm 56.4 \mathrm{pg} / \mathrm{ml}$. TARC levels decreased gradually with the age of children and correlated with activity and severity of $A D(r=0.58$ and 0.77 , accordingly, $p<0.001)$. The highest TARC levels are registered in patients with severe AD.

Conclusions. Biomarkers, such as TARC, can be used in pediatric practice to accurately assess the grade of invisible subclinical disorders and the severity of AD.
\end{abstract}

Keywords: atopic dermatitis, serum thymus and activation-regulated chemokine (TARC), children

\author{
Abbreviations \\ $\mathrm{AD}$ - atopic dermatitis \\ TARC - Thymus and Activation-Regulated Chemokine \\ SCORAD Index - Severity scoring of atopic dermatitis \\ $\mathrm{DC}$ - dendritic cell \\ $\mathrm{IL}$ - interleukin
}

LC - Langerhans cell

LDH - lactate dehydrogenase

Th - T-helper cell

TLR - Toll-like receptor

$\mathrm{TNF}$ - tumor necrosis factor

\section{INTRODUCTION}

In recent years, the researcher's concern in atopic dermatitis (AD) has significantly increased, due to the rapid prevalence elevation of the disease in different regions of the world [1]. AD usually presents during early infancy and childhood, but it can persist or start in adulthood. The lifetime prevalence of $\mathrm{AD}$ is 10-
$20 \%$ in children and $1-3 \%$ in adults [2]. The research over the last decade has revealed the genetic, ecological and immunological pathogenetic factors of $\mathrm{AD}$ [35]. It has been shown that Levels of serum lactate dehydrogenase (LDH) [7] and total immunoglobulin (Ig) E [8-9] and peripheral eosinophil counts [10] are well known to be correlated with AD severity. In the search for fundamental pathogenic mechanisms and 
the options improvements for prevention and treatment, more and more attention is paid to the state of the immune system [11]. It is known that $\mathrm{AD}$ is characterized by infiltration of Th2 cells into affected skin. Infiltration of inflammatory cells in the tissue is mediated by specific chemokines. An important chemokine is Thymus- and Activation-Regulated Chemokine (TARC), described in 1996 [12]. The TARC receptor is CCR4, which is expressed mainly on the skin, skin lymphocyte antigen-positive (CLA +) T-cells [13]. In vitro studies have shown that TARC causes selective lymphocyte migration of the phenotype Th2 [14]. Infiltration of effector / memorizing CD4 + T-cells of Th2 phenotype in the skin or respiratory tract plays an important role in the pathogenesis of allergic diseases, such as AD [15]. Chemokin TARC belongs to the CC subfamily, whose members are synthesized in thymus and also produced by dendritic cells, endothelial cells, keratinocytes, bronchial epithelium cells and fibroblasts [16-18]. The TARC protein is a ligand for CCchemokine receptors types 4 (CCR4) and 8 (CCR8) and it facilitates to replenishing the cell population that synthesizes these receptors, for example, Th2 cells [19-21]. Chemokine TARC and CCR4 receptor play an important role in the pathogenesis of $\mathrm{AD}$, which is considered to be the 7b2-dominant disease. Recently, [21] it had been shown, that TARC levels in blood serum have been elevated in patients with AD. In addition, they had shown that TARC levels correlate with the severity of $\mathrm{AD}[22]$. The results of recent studies [23-26] suggest, that chemokine TARC plays an important role in the pathogenesis of $\mathrm{AD}$. Abnormally high TARC levels are considered to reflect the presence of vicious spirals of positive feedback (Fig. 1), [26].

The purpose of the study is to investigate TARC levels in blood serum of children of different ages with different $\mathrm{AD}$ severity degrees.

\section{METHODS}

The scrunity of immune status was conducted in 168 children with $\mathrm{AD}$, aged 1 to 18 years, who were treated at Chernivtsi Oblast Children's Clinical Hospital during 2012-2017 years. The average age of AD patients was $7.4 \pm 0.6$ years, among them: 108 boys and 60 girls. The inclusion criteria in the study were: age of patients from 1 to 18 years; residence in Chernivtsi region; confirmed $\mathrm{AD}$. The exclusion criteria were: age of children under 1 year; combined allergic and other pathology of inflammatory genesis, use of corticosteroids and antihistamines during the last two weeks before the study. The control group consisted of 60 practically healthy children. The criteria for inclusion of children in the control group were: the absence of an allergic disease, not-burdened hereditary history of atopy; the absence of chronic and infectious diseases for 3 months before the survey; compliance with the normal parameters of the general analysis of blood and urine in the age.

Diagnosis of AD in children was exposed according to the diagnostic criteria of J. M. Hanifin and G. Rajka [27]. Children were divided into groups according to the severity of the clinical course of the disease (mild, moderate, severe). The severity of AD was set by the SCORAD Index [28]. The intensity of clinical

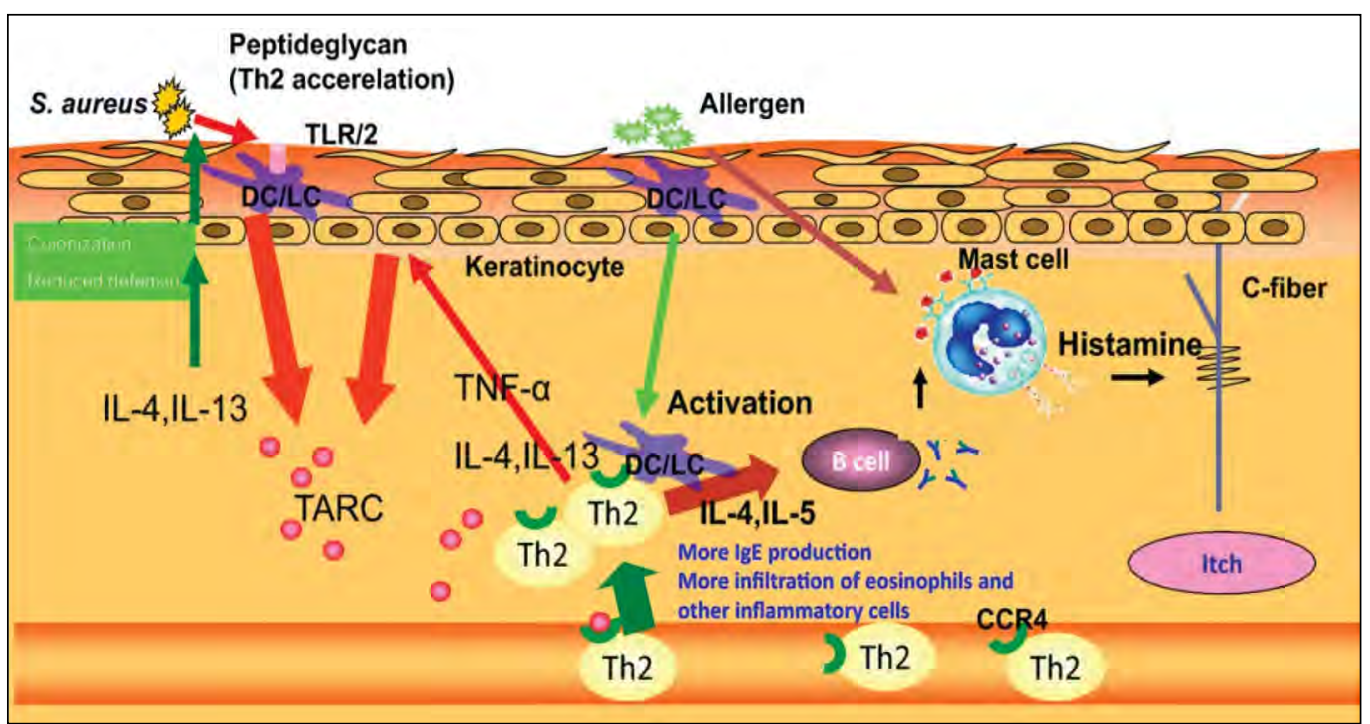

FIGURE 1. Speculated mechanism underlying the abnormally high serum thymus and activationregulated chemokine (TARC) levels characterized by vicious inflammatory spirals of positive feedback. DC, dendritic cell; IL, interleukin; LC, Langerhans cell; $L D H$, lactate dehydrogenase; Th, T-helper cell; TLR, Toll-like receptor; TNF, tumor necrosis factor [26] 
manifestations was scaled from 0 to 3 points: $0-$ absent, 1 - weak, 2 - moderately expressed, 3 - acutely expressed. Prevalence was evaluated according to the rule of "nine", where the area of the palmar surface of the wrist is taken as unit. The SCORAD Index formula is: $\mathrm{A} / 5+7 \mathrm{~B} / 2+\mathrm{C}$. In this formula, " $\mathrm{A}$ " is defined as the extent $(0-100)$, " $\mathrm{B}$ " is defined as the intensity $(0-18)$ and " $\mathrm{C}$ " is defined as the subjective symptoms (0-20). The maximal score of the SCORAD Index is 103 . Children were divided into groups according to the severity of the clinical course of the disease (light - up to 20 points, moderate $-20-40$ points, severe - more than 40 points). Medical intervention included a collection of 3-5 $\mathrm{ml}$ of blood from the elbow vein by the single use system BD Vacutainer Sofety-Lok (Bectar Dickinson and Company, USA). The IgE level was determined by an indirect immunofluorescence method using an auto-analyzer, and the test was considered positive at $\operatorname{IgE}>0.35 \mathrm{kE} / 1$.

TARC measurements in serum were performed by a plate (Becton Dickinson Franklin Lakes, NJ), coated with mouse monoclonal antibodies against human TARC (MAB364, R \& D Systems, Abingdon, UK). The optical densities were measured at $450 \mathrm{~nm}$ using Bio-Rad microplate reader (Biorad Laboratories, Inc., Hercules, CA). A recombinant human TARC (364DN, R \& D Systems) was used as a standard. The concentration was calculated according to the standard curve, obtained by the curve selection program. The minimum TARC level determined was $20 \mathrm{pg} / \mathrm{ml}$. Indicators were considered normal: Infant $1-2$ years: $<$ $998 \mathrm{pg} / \mathrm{ml}$, Child 2-18 years: $<743 \mathrm{pg} / \mathrm{ml}$ [29]. The statistical processing of the study results were carried out by standard algorithms of variation statistics, for calculations were used the Excel software (Microsoft Office, USA), Statistica 6.0 and the on-line SISA calculator (Simple Interactive Statistical Analysis), using correlation and parametric analysis. Average values were given as $(\mathrm{M} \pm \mathrm{m})$, where $\langle\mathrm{M} »$ is the average value of the indicator, «m» is the standard error of the average; «n» - the volume of the analyzed group. Data was analyzed using the Mann-Whitney U-criterion. Correlation coefficients were determined using Spirman's rank correlation test. All comparisons were 2 -sided. The values $\mathrm{p}<0.05$ were considered statistically significant.

\section{RESULTS}

Often, AD has occurred in young children, particularly from 2 to 6 years of age. According to the results of the study, the most prevalent in children with $\mathrm{AD}$ is food sensibilisation, which is found in $89.9 \%$ of cases. Almost half of the patients were sensitive to home dust and bacterial allergens, one third - to the medicinal ones; and about one quarter - to the pillow feathers, epidermal and pollen allergens, and in $48.2 \%$ of cases - in combination with each other (Fig. 2).

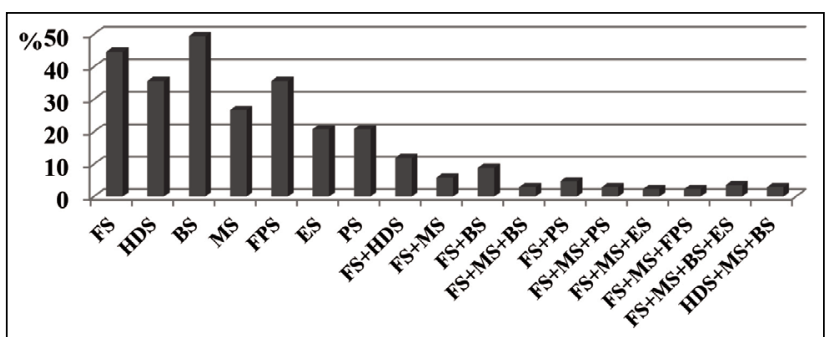

FIGURE 2. FS - food sensibilisation, HDS - home dust sensibilisation, BS - bacterial sensibilisation, MS - medical sensibilisation, FPS - feather pillow sensibilisation, ES - epidermal sensibilisation, PS - pollen sensibilisation

With age, the level of allergenic IgE in the blood of patients with $\mathrm{AD}$ and sensibilisation increased (Table 1).

TABLE 1. Age dynamics of IgE parameters in the blood of examined children

\begin{tabular}{|l|c|c|c|c|}
\hline \multirow{2}{*}{ Indicator } & \multicolumn{4}{|c|}{ Age (years) } \\
\cline { 2 - 5 } & $\mathbf{1 - 6}$ & $\mathbf{7 - 1 0}$ & $\mathbf{1 1 - 1 4}$ & $\mathbf{1 5 - 1 8}$ \\
\hline $\operatorname{IgE}, \mathrm{kO} / \mathrm{I}$ & $80.6 \pm 19.1$ & $106.6 \pm 23.1$ & $234.9 \pm 22.8^{*}$ & $312.5 \pm 33.9 * * *$ \\
\hline
\end{tabular}

Note: *the indicator difference in groups of 7-10 years and 11-14 probable, **the indicator difference in groups of 11-14 years old and 15-18 probable, $p<0,05$.

Most children under observation had a light or moderate severity of AD. The distribution of children is presented in Table 2 .

TABLE 2. Distribution of children with $A D$ according to age and severity of $A D$

\begin{tabular}{|c|c|c|c|c|}
\hline \multirow{2}{*}{$\begin{array}{c}\text { Age } \\
\text { (years) }\end{array}$} & \multicolumn{3}{|c|}{ Severity degree of AD (Number) } & \multirow{2}{*}{ Total } \\
\hline & light & moderate & severe & \\
\hline 1 & 4 & 2 & 2 & 8 \\
\hline 2 & 5 & 3 & 2 & 10 \\
\hline 3 & 8 & 5 & 4 & 17 \\
\hline 4 & 8 & 5 & 3 & 16 \\
\hline 5 & 6 & 6 & 3 & 15 \\
\hline 6 & 7 & 3 & 2 & 12 \\
\hline 7 & 5 & 6 & 0 & 11 \\
\hline 8 & 4 & 3 & 3 & 10 \\
\hline 9 & 4 & 3 & 2 & 9 \\
\hline 10 & 5 & 3 & 2 & 10 \\
\hline 10 & 3 & 4 & 3 & 10 \\
\hline 11 & 4 & 2 & 2 & 8 \\
\hline 12 & 3 & 3 & 1 & 7 \\
\hline 13 & 4 & 1 & 1 & 6 \\
\hline 14 & 3 & 2 & 0 & 5 \\
\hline 16 & 2 & 2 & 0 & 4 \\
\hline 17 & 3 & 2 & 0 & 5 \\
\hline 18 & 4 & 1 & 0 & 5 \\
\hline Total & 80 & 56 & 30 & 168 \\
\hline
\end{tabular}


TARC levels in serum were increased in all AD patients with a statistically significant $(\mathrm{p}<0.001)$ compared to healthy children (Table 3 ). Thus, the average indicator in the group of children with $\mathrm{AD}$ was $1322.8 \pm 114.6 \mathrm{pg} / \mathrm{ml}$, whereas in the group of healthy children $-399.8 \pm 56.4 \mathrm{pg} / \mathrm{ml}$. The levels of TARC decreased gradually with the age of children. The highest TARC levels were found in children with AD of the first year of life (from 1,356 to $1,848 \mathrm{pg} / \mathrm{ml}$, with an average value of $1,655 \pm 125.6 \mathrm{pg} / \mathrm{ml}$ ).

TARC levels in serum correlated with activity and severity of $\mathrm{AD}(\mathrm{r}=0.58$ and 0.77 , respectively, $\mathrm{p}<$ $0.001)$. The highest TARC levels were recorded in patients with severe AD (Table 4, Figure 3). In children with AD and sensibilisation to certain factors, TARC levels were higher than those in children with $\mathrm{AD}$, but without definite sensibilisation.

TABLE 3. TARC levels $(\mathrm{pg} / \mathrm{ml})$ in blood serum of children with $A D$

\begin{tabular}{|c|c|c|}
\hline $\begin{array}{c}\text { Age } \\
\text { (years) }\end{array}$ & Children with AD ( $\mathbf{n}=\mathbf{1 6 8 )}$ & Healthy children $(\mathbf{n = 6 0 )}$ \\
\hline 1 & $1,655 \pm 125.6^{*}$ & $655 \pm 25.6$ \\
\hline 2 & $1,497 \pm 134.6^{*}$ & $643.8 \pm 12.9$ \\
\hline 3 & $1,346.2 \pm 112.5^{*}$ & $605.5 \pm 32.6$ \\
\hline 4 & $1,309.5 \pm 105.1^{*}$ & $554.3 \pm 21.7$ \\
\hline 5 & $1,295.7 \pm 123.7^{*}$ & $505.8 \pm 30.4$ \\
\hline 6 & $1,264.1 \pm 99.3^{*}$ & $493.2 \pm 12.6$ \\
\hline 7 & $1,256.8 \pm 125.8^{*}$ & $455.5 \pm 26.3$ \\
\hline 8 & $1,250.9 \pm 95.6^{*}$ & $412.9 \pm 25.7$ \\
\hline 9 & $1,207.7 \pm 102.6^{*}$ & $399.8 \pm 19.6$ \\
\hline 10 & $1,200.9 \pm 98.9^{*}$ & $387.2 \pm 25.3$ \\
\hline 10 & $1,189.4 \pm 112.6^{*}$ & $379.9 \pm 17.6$ \\
\hline 11 & $1,178.6 \pm 121.2^{*}$ & $378.8 \pm 19.1$ \\
\hline 12 & $1,189.3 \pm 93.6^{*}$ & $370.0 \pm 19.6$ \\
\hline 13 & $1,099.4 \pm 89.8^{*}$ & $367.4 \pm 25.6$ \\
\hline 14 & $1,110.7 \pm 101.1^{*}$ & $359.8 \pm 18.7$ \\
\hline 16 & $989.3 \pm 85.6^{*}$ & $345.6 \pm 12.9$ \\
\hline 17 & $967.9 \pm 97.7^{*}$ & $308.8 \pm 21.1$ \\
\hline 18 & $912.8 \pm 76.6^{*}$ & $299.4 \pm 16.6$ \\
\hline
\end{tabular}

Note: ${ }^{*} p<0.01$.

TABLE 4. TARC levels $(\mathrm{pg} / \mathrm{ml})$ in blood serum of children with $A D$

\begin{tabular}{|c|c|l|c|}
\hline \multirow{2}{*}{ Index } & \multicolumn{3}{|c|}{ Severity degree of AD } \\
\cline { 2 - 4 } & light $(\mathbf{n}=\mathbf{8 0})$ & moderate $(\mathbf{n}=56)$ & severe $(\mathbf{n}=\mathbf{3 0})$ \\
\hline TARC, $\mathrm{pg} / \mathrm{ml}$ & $956.6 \pm 76.1^{*}$ & $1,366.9 \pm 67.1^{*}$ & $1,646 \pm 54.6^{* *}$ \\
\hline
\end{tabular}

Note: ${ }^{*} p<0.01 * *-p<0.001$.

\section{DISCUSSIONS}

The results of our and other [30-31] studies indicate a dynamic increase in the prevalence of AD. In our studies, we confirmed the recommendations [32] to grade the severity of $\mathrm{AD}$, while agreeing that the
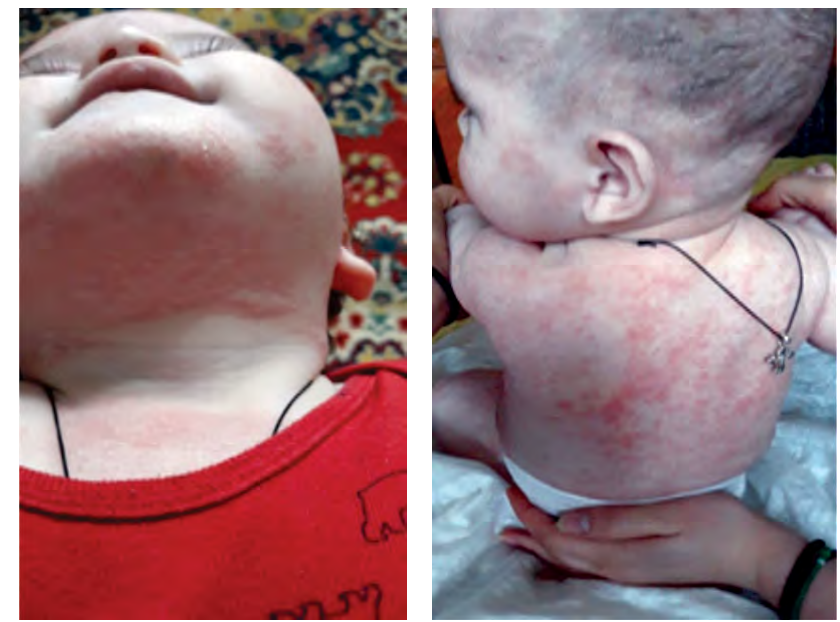

FIGURE 3. A 6-months-old boy with severe atopic dermatitis. His serum thymus and activation-regulated chemokine level were $1684 \mathrm{pg} / \mathrm{ml}$

best tool for assessing clinical signs of $A D$ is the SCORAD scale. Other authors recommend using for children with eczema paediatric version- ISS and also Patient-Oriented Eczema Measure (POEM), PatientOriented SCOring Atopic Dermatitis (PO-SCORAD), Self-Administered Eczema Area and Severity Index (SA-EASI) and adapted SA-EASI, which are currently the most appropriate instruments and therefore have the potential to be recommended as core symptom instrument in future clinical trials. These findings will be utilized for the development of a core outcome set for atopic eczema [33-34]. Attention is paid to assessing the quality of sleep in patients with $\mathrm{AD}$ [35]. In recent decades, a large number of studies have been published to investigate the connection between $\mathrm{AD}$ severity and various biomarkers, the TARC level in particular [36-37]. This indicator is important for assessing the severity of AD because of the diversity of clinical manifestations and the complexity of their assessment in childhood. Even in a healthy population, TARC levels in serum are higher in children than in adults, according to the studies [38]. We conclude that, if the initial skin lesions are localized, high TARC levels in serum indicate a strong disease activity and this may lead to immediate eczema development and increased Ig E levels with multiple sensibilisation to different factors. The levels of TARC in cord blood serum can predict the development of $\mathrm{AD}$ in childhood [39]. However, the issue of defining TARC as an absolute biomarker of AD is currently under discussion. The feature of elevated TARC level in serum is not specific to $\mathrm{AD}$, because its levels change with other skin lesions [40-42]. In our opinion, TARC levels can be used as a marker of predicting the development and severity of AD. Persistent high levels of serum-like TARC may indicate inadequate treatment, but more clinical studies are required. 


\section{CONCLUSIONS}

Nowadays, for successful treatment of atopic dermatitis a certain and objective assessment of clinical manifestations is required. TARC can be considered as a useful clinical biomarker that can be used in pediatric practice to accurately assess invisible subclinical

\section{REFERENCES}

1. Siegfried EC, Hebert AA. Diagnosis of atopic dermatitis: Mimics, overlaps, and complications. Journal of Clinical Medicine. 2015; 4: 884-917.

2. Leung DY, Boguniewicz MD, Howell I, Nomura I, Hamid QA. New insights into atopic dermatitis. J Clin Invest. 2004;113:651.

3. Leung DY, Bieber T. Atopic dermatitis. Lancet. 2003;361:151-160.

4. Harris VR, Cooper AJ. Atopic dermatitis: the new frontier. Med J Aust. 2017; 207(8):351-356.

5. Lee J, Noh G, Lee S et al. Atopic dermatitis and cytokines: recent patents in immunoregulatory and therapeutic implications of cytokines in atopic dermatitis--part I: cytokines in atopic dermatitis. Recent Pat Inflamm Allergy Drug Discov. 2012;6(3):222-47.

6. Wen HJ, Wang YJ, Lin YC et al. Prediction of atopic dermatitis in 2-yr-old children by cord blood lgE, genetic polymorphisms in cytokine genes, and maternal mentality during pregnancy. Pediatr Allergy Immunol. 2011;22(7):695-703.

7. Mukai H, Noguchi T, Kamimura K, Nishioka K, Nishiyama S. Signifi- cance of elevated serum LDH (lactate dehydrogenase) activity in atopic dermatitis. J Dermatol. 1990; 17: 477-481.

8. Wuthrich B, Benz A, Skvaril F. IgE and lgG4 levels in children with atopic dermatitis. Dermatologica. 1983; 166: 229-235.

9. Gebhardt M, Wenzel HC, Hipler UC, Herrmann D, Wollina U. Monitoring of serologic immune parameters in inflammatory skin diseases. Allergy 1997; 52: 1087-1094.

10. Simon D, Braathen LR, Simon HU. Eosinophils and atopic dermatitis. Allergy. 2004; 59: 561-570.

11. Sayaseng KY, Vernon P. Pathophysiology and Management of Mild to Moderate Pediatric Atopic Dermatitis. J Pediatr Health Care. 2018; 32(2):2-12

12. Imai T, Yoshida T, Baba M, Nishimura M, Kakizaki M, Yoshie O. Molecular cloning of a novel T cell-directed CC chemokine expressed in thymus by signal sequence trap using Epstein-Barr virus vector. J Biol Chem. 1996; 271:1514-1521.

13. Bieber T. Atopic dermatitis. Ann Dermatol. 2010; 22: 125-137.

14. Vestergaard C, Bang K, Gesser B et al. Th2 chemokine, TARC, produced by keratinocytes may recruit CLA+CCR4 + lymphocytes into lesional atopic dermatitis skin. J Invest Dermatol. 2000; 115: 640-646.

15. Hijnen D, De Bruin-Weller M, Oosting B et al. Serum thymus and activation-regulated chemokine (TARC) and cutaneous T cell- attracting chemokine (CTACK) levels in allergic diseases: TARC and CTACK are disease-specific markers for atopic dermatitis. J Allergy Clin Immunol. 2004; 113: 334-340.

16. Hon KL, Leung TF, Ma KC, Li AM, Wong Y, Fok TF. Serum levels of cutaneous T-cell attracting chemokine (CTACK) as a laboratory marker of the severity of atopic dermatitis in children. Clin Exp Dermatol. 2004;29: 293-296.

17. 17.Kagami S, Kakinuma T, Saeki $\mathrm{H}$ et al. Significant elevation of serum levels of eotaxin-3/CCL26, but not of eotaxin-2/CCL24, in patients with atopic dermatitis: serum eotaxin-3/CCL26 levels reflect the dis- ease activity of atopic dermatitis. Clin Exp Immunol. 2003; 134: $309-313$.

18. Shoda T, Futamura K, Kobayashi $F$ et al. Expression of thymus and activation-regulated chemokine (TARC) by human dermal cells, but not epidermal keratinocytes. J Dermatol Sci. 2014;76(2):90-5.

19. Leung TF, Ma KC, Hon KL et al. Serum concentration of macrophagederived chemokine may be a useful inflammatory marker for disorders, assess the severity of atopic dermatitis and to predict its course. Further studies of TARC levels in tissues and peripheral blood in patients with atopic dermatitis may help to explain the role that this chemokine plays in the pathogenesis of the disease and pave the way for further therapeutic tactics.

assessing severity of atopic dermatitis in infants and young children. Pediatr Allergy Immunol. 2003; 14: 296-301.

20. Ahrens B, Schulz G, Bellach J, Niggemann B, Beyer K. Chemokine levels in serum of children with atopic dermatitis with regard to severity and sensitization status. Pediatr Allergy Immunol. 2015;26(7):634-40.

21. Shoda T, Futamura K, Kobayashi $F$ et al. Expression of thymus and activation-regulated chemokine (TARC) by human dermal cells, but not epidermal keratinocytes. J Dermatol Sci. 2014;76(2):90-5.

22. Fujisawa T, Nagao M, Hiraguchi $Y$ et al. Serum measurement of thymus and activation-regulated chemokine/CCL17 in children with atopic dermatitis: elevated normal levels in infancy and age-specific analysis in atopic dermatitis. Pediatr Allergy Immunol. 2009;20(7):63341.

23. Maeda S, Maeda S, Ohno K et al. Protease-activated receptor-2 induces proinflammatory cytokine and chemokine gene expression in canine keratinocytes. Vet Immunol Immunopathol. 2013; 153(1-2):1725.

24. Miyahara H, Okazaki N, Nagakura T, Korematsu S, Izumi T. Elevated umbilical cord serum TARC/CCL17 levels predict the development of atopic dermatitis in infancy.

25. Clin Exp Allergy. 2011; 41(2):186-91.

26. Saeki H. Biomarker of atopic dermatits - focusing on serum TARC/ CCL17 level as severity marker. Arerugi. 2013; 62(2):131-7. Japanese.

27. Kataoka Y. Thymus and activation-regulated chemokine as a clinical biomarker in atopic dermatitis. J Dermatol. 2014;41(3):221-9.

28. Hanifin JM. Diagnostic criteria for atopic dermatitis: consider the context. Arch Dermatol. 1999;135:1551.

29. Oranje AP.Practical issues on interpretation of scoring atopic dermatitis: SCORAD Index, objective SCORAD, patient-oriented SCORAD and Three-Item Severity score. Curr Probl Dermatol. 2011;41:149-155.

30. Fujisawa T, Nagao M, Hiraguchi $Y$, Katsumata $\mathrm{H}$, Nishimori $\mathrm{H}$ et al. Serum measurement of thy- mus and activation-regulated chemokine/ CCL17 in children with atopic dermatitis: elevated normal levels in infancy and age-specific analysis in atopic dermatitis. Pediatr Allergy Immunol 2009; 20: 633-641.

31. Bridgman AC, Eshtiaghi P, Cresswell-Melville A, Ramien M, Drucker. AM. The Burden of Moderate to Severe Atopic Dermatitis in Canadian Children: A Cross-Sectional Survey. Cutan J Med Surg. 2018 Jul/Aug; 22(4): 443-444.

32. Akdis CA, Akdis M, Bieber T, Bindslev-Jensen C, Boguniewicz M et al. European Academy of Allergology; Clinical Immunology/American Academy of Allergy, Asthma and Immunology/PRACTALL Consensus Group. Diagnosis and treatment of atopic dermatitis in children and adults: European Academy of Allergology and Clinical Immunology/ American Academy of Allergy, Asthma and Immunology/PRACTALL Consensus Report. Allergy. 2006; 61(8): 969-987.

33. Schmitt J, Langan S, Deckert S, Svensson A, von Kobyletzki L et al. Harmonising Outcome Measures for Atopic Dermatitis (HOME) Initiative. Assessment of clinical signs of atopic dermatitis: a systematic review and recommendation. J Allergy Clin Immunol. 2013;132(6):1337-47.

34. Gerbens LA, Prinsen CA, Chalmers JR, Drucker AM, von Kobyletzki $\mathrm{LB}$ et al. Harmonising Outcome Measures for Eczema (HOME) 
initiative. Evaluation of the measurement properties of symptom measurement instruments for atopic eczema: A systematic review. Allergy. 2017;72(1):146-163.

35. Ramirez FD, Chen S, Langan SM, Prather AA, McCulloch CE et al. Association of Atopic Dermatitis With Sleep Quality in Children. JAMA Pediatr. 2019 Mar 4:e190025.

36. Gohar MK, Atta AH, Nasr MM, Hussein DN. Serum Thymus and Activation Regulated Chemokine (TARC), IL- 18 and IL-18 Gene Polymorphism as Associative Factors with Atopic Dermatitis Egypt J Immunol. 2017;24(2):9-22.

37. Thijs J, Krastev T, Weidinger S, Buckens CF, de Bruin-Weller M et al. Biomarkers for atopic dermatitis: A systematic review and metaanalysis. Curr Opin Allergy Clin Immunol. 2015;15(5):453-60.

38. Mikiko KT, Kawakami YS. Serum thymus and activation-regulated chemokine (TARC) and interleukin-31 levels as biomarkers for monitoring in adult atopic dermatitis. 2014;75(3):204-207.

39. Jahnz-Rozyk K, Targowski T, Paluchowska E, Owczarek W, Kucharczyk A. Serum thymus and activation-regulated chemokine, macrophage-derived chemokine and eotaxin as markers of severity of atopic dermatitis. Allergy. 2005; 60: 685-688.

40. Miyahara H, Okazaki N, Nagakura T, Korematsu S, Izumi T. Elevated umbilical cord serum TARC/CCL17 levels predict the development of atopic dermatitis in infancy. Clin Exp Allergy. 2011; 41: 186-191.

41. Saeki H, Tamaki K. Thymus and activation regulated chemokine (TARC)/CCL17 and skin diseases. J Dermatol Sci. 2006; 43: 75-84.

42. Quaglino P, Caproni M, Antiga E, Del Bianco E, Osella-Abate S et al. Serum levels of the Th1 promoter IL-12 and the Th2 chemokine TARC are elevated in erythema multiforme and Stevens-Johnson syndrome/ toxic epidermal necrolysis and correlate with soluble Fas ligand expression. An immunoenzymatic study from the Italian Group of Immunopathology. Dermatology. 2007; 214: 296-304.

43. Ono S, Otsuka A, Miyachi Y, Kabashima K. Subcorneal pustular dermatosis exhibiting a high serum TARC/CCL17 level. Case Rep Dermatol 2013; 5: 38-42. 